\title{
Effects of hydrogen peroxide on the metabolism of human rheumatoid and osteoarthritic synovial fibroblasts in vitro
}

\author{
Nongporn Hutadilok, Margaret M Smith, Peter Ghosh
}

\begin{abstract}
The effects of hydrogen peroxide $\left(\mathrm{H}_{2} \mathrm{O}_{2}\right)$ on the metabolism of cultured human synovial fibroblasts derived from joints of four patients with rheumatoid arthritis and three with osteoarthritis have been investigated. The exposure of rheumatoid cell cultures to this oxygen derived species at sublethal concentrations (1-100 $\mu \mathrm{mol} / \mathrm{l})$ induced a dose related inhibition of both hyaluronic acid (HA) and DNA synthesis. In contrast, in osteoarthritic cell lines a biphasic response was shown. At low concentrations of $\mathrm{H}_{2} \mathrm{O}_{2}(<10 \mu \mathrm{mol} / \mathrm{l})$ a stimulatory effect on $\mathrm{HA}$ synthesis was noted, whereas in the presence of higher concentrations ( $>10 \mu \mathrm{mol} / \mathrm{l})$ a significant inhibition of synthesis occurred. These deleterious effects of $\mathrm{H}_{2} \mathrm{O}_{2}$ were partially reduced by the addition of catalase to the culture media. The finding that both HA and DNA synthesis were inhibited at concentrations of $\mathrm{H}_{2} \mathrm{O}_{2}$ less than those which caused loss of cell integrity $(>200$ $\mu \mathrm{mol} / \mathrm{l})$ suggests oxidation of intracellular components, such as glyceraldehyde-3-phosphate dehydrogenase, and subsequent depletion of ATP concentrations.
\end{abstract}

In inflammatory arthritides such as rheumatoid arthritis infiltration of large numbers of polymorphonuclear leucocytes and macrophages into the joint space occurs. ${ }^{1}$ When activated, these phagocytic cells are known to undergo a respiratory burst which is accompanied by the generation of highly reactive oxygen species, superoxide anion $\left(\mathrm{O}_{2}^{-}\right)$, and hydrogen peroxide $\left(\mathrm{H}_{2} \mathrm{O}_{2}\right)^{2}$ The release by these cells of $\mathrm{O}_{2}^{-}$and $\mathrm{H}_{2} \mathrm{O}_{2}$ can also result in the formation of other metabolites such as hydroxyl radical $\left(\mathrm{OH}^{\circ}\right)$, singlet oxygen, and hypochlorous acid. ${ }^{3}$ The liberation of these oxygen derived reactive species upon stimulation of phagocytes in the synovial cavity by immune complexes, particulate matter-for example, urate or pyrophosphate crystals, cartilage debris-and other inflammatory agents is considered to be responsible for the decrease of synovial fluid viscosity owing to depolymerisation of hyaluronic acid (HA). 4-10

Additionally, free radicals within inflamed joints may be generated from other sources, including the prostaglandin cascade and the autoxidation of small molecules such as flavoproteins, hydroquinones, pyrogallols, etc. ${ }^{11}$ Even though it has been realised that the production of oxygen radicals during inflammation can be limited by oxygen concentration ${ }^{12}$ and that inflammatory joints generally have lower oxygen tensions than normal joints, ${ }^{13}$ there is considerable indirect and direct evidence showing that oxidant scavenging activity in rheumatoid synovial fluid is low and is not sufficient to control damage in the joint mediated by reactive oxygen species. ${ }^{14-17}$

Furthermore, in vitro studies have shown the ability of the reactive oxygen metabolites $\left(\mathrm{O}_{2}^{-}\right.$ and $\mathrm{OH}^{\bullet}$ radicals) generated by different radical producing systems to degrade a number of extracellular matrix components, including collagen $^{18}$ and proteoglycans. ${ }^{18-22}$ More recently, $\mathrm{H}_{2} \mathrm{O}_{2}$ has been shown to depolymerise the proteoglycan aggregates of human articular cartilage in vitro. ${ }^{23}$ It has been suggested that this aggregate disruption may be attributed to degradation of HA and chemical modification of link proteins which are necessary for stabilisation of proteoglycan aggregates. ${ }^{24}$

In addition to its ability to mediate fragmentation of proteoglycans, $\mathrm{H}_{2} \mathrm{O}_{2}$ has been shown to inhibit in a concentration dependent manner in vitro proteoglycan and HA biosynthesis by bovine and murine articular cartilage chondrocytes. $^{25-27}$ Exposure of endothelial cells, ${ }^{28} 29$ skin fibroblasts, ${ }^{30}{ }^{31}$ epithelial cells, ${ }^{32}$ hepatocytes, ${ }^{33}$ and tumour cells ${ }^{34}$ to $\mathrm{H}_{2} \mathrm{O}_{2}$ generating systems has also been reported to cause permanent cellular injuries. It has been proposed that $\mathrm{H}_{2} \mathrm{O}_{2}$ penetrates the cell membrane, inducing degradation of $\mathrm{DNA}^{3536}$ and suppression of ATP production. ${ }^{37} 38$

In inflamed synovial joints fibroblasts of the synovial lining (type $\mathrm{B}$ cell) are exposed to $\mathrm{H}_{2} \mathrm{O}_{2}$ liberated from stimulated phagocytes, ${ }^{39}$ but the effects that this oxidant might have on the metabolism of these cells had not been reported. We therefore undertook this study to consider that question.

The results obtained indicate that the metabolism of synovial fibroblasts derived from both rheumatoid and osteoarthritic knee joints can be modified by $\mathrm{H}_{2} \mathrm{O}_{2}$; the effects produced depending on the concentration of $\mathrm{H}_{2} \mathrm{O}_{2}$ to which these cells are exposed.

\section{Materials and methods}

\section{MATERIALS}

Dulbecco's modified Eagle's medium and trypsin (from porcine pancreas (EC 3.4.21.4)) were products of Gibco Laboratories, Grand Island, NY, USA. Collagenase type I (from Clostridium histolyticum (EC 3.4.24.3)), diethylenetriaminepenta-acetic acid, and catalase (from bovine liver (EC 1.11.1.6)) were purchased from Sigma Chemical Co, St Louis, MO, USA. Fetal calf serum was obtained from 
Flow Laboratories (Australia) Pty Ltd, Seven Hills, NSW, Australia. Gentamicin was from David Bull Laboratories Pty Ltd, Mulgrave, Victoria, Australia. The $\left[{ }^{3} \mathrm{H}\right]$ acetic acid, sodium salt (specific activity 74-185 $\mathrm{GBq} / \mathrm{mmol}$ ), [methyl- ${ }^{3} \mathrm{H}$ ] thymidine (specific activity 185 $\mathrm{GBq} / \mathrm{mmol}$ ) were purchased from Amersham Australia Pty Ltd, North Ryde, NSW, Australia. Hyaluronidase (from Streptomyces hyalurolyticus (EC 4.2.99.1)) and peroxidase (from horseradish roots (EC 1.11.1.7)) were supplied from Miles Laboratories Australia Pty Ltd, Epping, NSW, Australia. Superoxide dismutase (Palosein (EC 1.15.1.1)) was purchased from Intervet (Australia) Pty Ltd, Artarmon, NSW, Australia. Diphenylamine was manufactured by Ajax Chemicals, Auburn, NSW, Australia. Hydrogen peroxide (pure medicinal quality) was from Pacific Mfg Co Pty Ltd, Balmain, NSW, Australia and phenol red from Alpha Chemicals (Australia) Pty Ltd, Dee Why, NSW, Australia. Sepharose CL-2B together with all chromatography instruments were supplied by Pharmacia (Australia) Pty Ltd, North Ryde, NSW, Australia. All other reagents were of analytical grade and double distilled water was used in all buffer and media preparations.

SOURCES OF SYNOVIAL TISSUE

Synovial tissue from osteoarthritic and rheumatoid arthritic knee joints was provided by $\mathrm{Dr}$ David Sonnabend and Dr Nigel Hope, from patients undergoing total joint replacement surgery at the Royal North Shore Hospital of Sydney or the North Sydney Community Hospital. The classification of the synovium as being derived from osteoarthritic or rheumatoid joints was determined by the attending surgeons using both clinical and pathological methods of assessment. Altogether seven cell lines (four rheumatoid, three osteoarthritic) were used in this study.

SYNOVIAL FIBROBLAST CULTURE METHOD Synovial fibroblasts were prepared from the tissues described above by the Smith and Ghosh modification $^{40}$ of the Dayer et al procedure. ${ }^{41}$ Briefly, explants of the synovial membrane were washed three times and finely diced in sterile Dulbecco's calcium and magnesium free phosphate buffered saline (CMF-PBS). Tissues were then placed in Dulbecco's modified Eagle's medium containing $23 \mathrm{mM}$ sodium bicarbonate, $40 \mu \mathrm{g} / \mathrm{ml}$ gentamicin, and $4 \mathrm{mg} / \mathrm{ml}$ collagenase for three to four hours at $37^{\circ} \mathrm{C}$ with occasional mixing. After the incubation, an equal volume of $0.05 \%(w / v)$ trypsin and $0.02 \%(w / v)$ ethylenediaminetetra-acetic acid (EDTA) in CMFPBS was added. Incubation was continued for one hour under the same conditions as above. The suspension was then centrifuged for five minutes at $400 \mathrm{~g}$. The supernatant was aspirated and the cell pellet washed three times in Dulbecco's modified Eagle's medium containing $23 \mathrm{mM}$ sodium bicarbonate, $40 \mu \mathrm{g} / \mathrm{ml}$ gentamicin, and $10 \%(\mathrm{v} / \mathrm{v})$ heat inactivated fetal calf serum, and then plated in $75 \mathrm{~cm}^{2}$ culture flasks (Lux; Miles Laboratories). The fibroblasts were grown and maintained in a monolayer culture in the latter previously described medium, at $37^{\circ} \mathrm{C}$ in a humidified atmosphere of $95 \%(v / v)$ air and $5 \%(v / v)$ carbon dioxide. The medium was changed every two to three days and the cells were subcultured on reaching confluency.

\section{HYALURONIC ACID SYNTHESIS}

Cells, passaged five to eight times, were seeded into $2 \mathrm{~cm}^{2}$ wells ( 24 wells/plate) (Linbro; Flow Laboratories) at a density of 30000 cells/well. Once they reached $70 \%$ confluency (three to four days later depending on the cell line, at which the rate of HA synthesis was found to be greatest $^{42}$ ) the medium was replaced with $0.4 \mathrm{ml}$ of medium containing $925 \mathrm{kBg} / \mathrm{ml}\left[{ }^{3} \mathrm{H}\right]$ acetate in the presence and absence of test substances. The cells were further incubated under standard conditions for 24 hours. The medium was then removed from each well and the cell layer was washed twice with $0.3 \mathrm{ml}$ of CMF-PBS. The washings were combined with the media and assayed for radiolabelled HA by the method described by Smith and Ghosh. ${ }^{40}$ In this assay the media and washings from each culture well were dialysed against $0.1 \mathrm{M}$ sodium acetate $\mathrm{pH}$ 5.6 at $4^{\circ} \mathrm{C}$ over two days with four changes. After dialysis each sample was made up to $2 \mathrm{ml}$ and then $2 \times 0.8 \mathrm{ml}$ aliquots were taken. To one set of these aliquots was added five turbidity reducing units (TRU) (one TRU $=$ the amount of enzyme which causes a $50 \%$ decrease in optical density at $660 \mathrm{~nm}$ in 30 minutes at $60^{\circ} \mathrm{C}$ ) of Streptomyces hyaluronidase. Aliquots, both with and without enzyme were incubated at $60^{\circ} \mathrm{C}$ for three hours. After incubation the samples were dialysed as previously. The redialysed sample volumes were then made up to $2 \mathrm{ml}$, and a $0.5 \mathrm{ml}$ aliquot was counted for radioactivity.

The amount of newly synthesised HA was calculated as disintegrations per minute (dpm) of the blank sample minus the dpm of the hyaluronidase treated sample. This value was corrected for cell number or DNA content to eliminate a potential source of variation between the wells. Results were expressed as a percentage in HA production when compared with the control (no test substances) cultures.

The measurement of DNA in samples was determined by trypsinising cells with $0 \cdot 1 \%$ $(\mathrm{w} / \mathrm{v})$ trypsin and $0.02 \%(\mathrm{w} / \mathrm{v})$ EDTA in CMFPBS, then solubilising the DNA in $0.5 \mathrm{M}$ perchloric acid, followed by measuring DNA concentration with the diphenylamine reagent as described by Burton. ${ }^{43}$

\section{DNA SYNTHESIS}

Cells were plated in $0.38 \mathrm{~cm}^{2}$ wells ( 96 wells/ plate) (Linbro; Flow Laboratories) at a density of 15000 cells/well. After 24 hours' incubation in $0.2 \mathrm{ml}$ Dulbecco's modified Eagle's medium containing $10 \%(\mathrm{v} / \mathrm{v})$ fetal calf serum the culture medium was changed and cells were further incubated under the same culture conditions but in media containing $185 \mathrm{kBq} / \mathrm{ml}\left[{ }^{3} \mathrm{H}\right]$ - 
thymidine in the presence and absence of test substances for 24 hours. The media were then discarded and the cell layers washed twice with CMF-PBS, and released with $0 \cdot 2 \%(w / v)$ trypsin, $0.1 \%(w / v)$ EDTA in CMF-PBS. The cells were lysed with distilled water and the lysates filtered through glass fibre filters (Titertek; Flow Laboratories). The filters were then air dried, and the radioactivity was determined by scintillation spectrophotometry.

Results were expressed as a percentage in $\left[{ }^{3} \mathrm{H}\right]$ thymidine uptake when compared with the control (no test substances) samples.

\section{GEL EXCLUSION CHROMATOGRAPHY}

Tissue culture media $(1 \mathrm{ml})$ directly obtained from the $\left[{ }^{3} \mathrm{H}\right] \mathrm{HA}$ synthesis experiments were chromatographed on a Sepharose CL-2B column $(1.5 \times 90 \mathrm{~cm})$ equilibrated with $0.5 \mathrm{M}$ sodium acetate $\mathrm{pH} 6.8$ at $4^{\circ} \mathrm{C}$, eluting at $12 \mathrm{ml} / \mathrm{h}$. The column was calibrated with highly purified HA of molecular weight $3.8 \times 10^{6}$ (Healon; Pharmacia Leo Therapeutics AB, Uppsala, Sweden) and $\left[{ }^{3} \mathrm{H}\right]$ acetate to mark the void volume and total volume respectively. Fractions of $2 \mathrm{ml}$ were collected and monitored for radioactivity.

\section{CELL INTEGRITY}

Cell membrane integrity of the treated fibroblasts was measured by the trypan blue exclusion assay. An equal volume of $0 \cdot 1 \%(w / v)$ trypan blue in CMF-PBS was added to a suitable cell suspension and the number of intact and damaged - that is, stained-cells was counted with a haemocytometer. The number of intact cells was expressed as a percentage of the total number of cells.

\section{DETERMINATION OF HYDROGEN PEROXIDE \\ $\left(\mathrm{H}_{2} \mathrm{O}_{2}\right)$}

The concentration of stock $\mathrm{H}_{2} \mathrm{O}_{2}$ solutions was determined by $0.1 \mathrm{M}$ potassium permanganate titration, ${ }^{44}$ and the concentration of $\mathrm{H}_{2} \mathrm{O}_{2}$ remaining in the culture medium at various times during incubation with synovial cells was determined by the method used on the peroxidase dependent oxidation of phenol red by $\mathrm{H}_{2} \mathrm{O}_{2},{ }^{45}$ described by Pick. ${ }^{46}$ The assay was performed in a microtitre plate with a final concentration of phenol red of $0.56 \mathrm{mmol} / \mathrm{l}$ and of peroxidase 20 units $/ \mathrm{ml}$ in each well. (One unit = the amount of enzyme which catalyses the conversion of $1 \mu \mathrm{mol}$ peroxide per minute at $25^{\circ} \mathrm{C}$.) Absorbances were read at $620 \mathrm{~nm}$ instead of $600 \mathrm{~nm}$ as originally described.

\section{STATISTICAL METHODS}

The data generated on HA and DNA synthesis in the various cell lines, for each treatment group (three and six replicates in each group on HA and DNA synthesis respectively), were analysed by an unpaired Student's $t$ test. The null hypothesis was that test substances exerted no effects on HA or DNA synthesis with the control group for comparison. An effect was considered to occur when the difference between the two groups corresponded to $p \leqslant 0.05$.

\section{Results}

EFFECTS OF HYDROGEN PEROXIDE $\left(\mathrm{H}_{2} \mathrm{O}_{2}\right)$ ON HA SYNTHESIS

Figure 1 shows the effects of different concentrations of $\mathrm{H}_{2} \mathrm{O}_{2}$ on the incorporation of $\left[{ }^{3} \mathrm{H}\right]$ acetate into newly synthesised $\mathrm{HA}$ after incubation with the human synovial fibroblast cultures for 24 hours. Fibroblasts derived from osteoarthritic joints showed a biphasic response (fig 1A). Hydrogen peroxide concentrations of $10 \mu \mathrm{mol} / \mathrm{l}$ or less produced stimulation of $\mathrm{HA}$ synthesis in these cells, the maximum being $123 \%$ above the control value at $2 \mu \mathrm{mol} / \mathrm{l}$. The increased biosynthesis of radiolabelled $\mathrm{HA}$ at 5 $\mu \mathrm{mol} / 1 \mathrm{H}_{2} \mathrm{O}_{2}$ could also be shown by Sepharose CL-2B chromatography of the media from the osteoarthritic cells. A higher proportion of high molecular weight ${ }^{3} \mathrm{H}$ labelled $\mathrm{HA}$ (confirmed by its susceptibility to Streptomyces hyaluronidase digestion) eluted in the void volume fraction than in media from the control cultures (fig 2). At concentrations above $10 \mu \mathrm{mol} / \mathrm{l}$, however, $\mathrm{H}_{2} \mathrm{O}_{2}$ inhibited $\mathrm{HA}$ synthesis in the osteoarthritic cell line in a concentration dependent manner (fig 1A). Sepharose CL-2B chromatography of the media from the $20 \mu \mathrm{mol} / \mathrm{l}$ cultures confirmed the low incorporation of radioactivity into the high molecular weight $\mathrm{HA}$ fraction (fig 2).

In contrast with the osteoarthritic cell lines, no stimulation of $\mathrm{HA}$ synthesis by $\mathrm{H}_{2} \mathrm{O}_{2}$ was
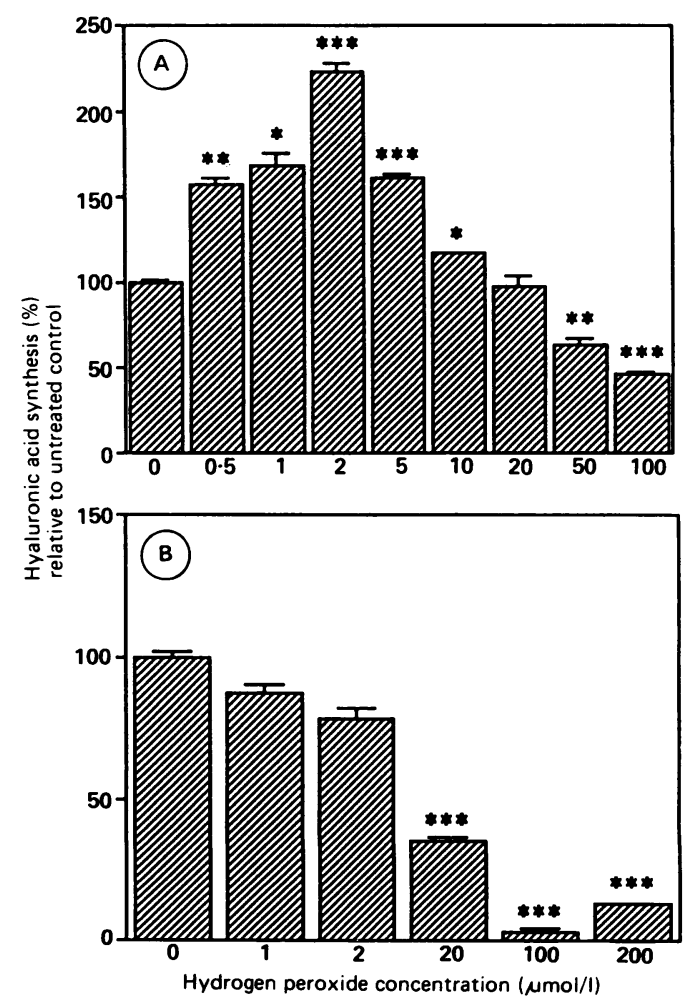

Figure 1 Effects of various concentrations of hydrogen peroxide on the synthesis of $\left[{ }^{3} \mathrm{H}\right]$ hyaluronic acid by synovial fibroblasts derived from $(A)$ osteoarthritic and $(B)$ rheumatoid arthritic joints. Each column represents the mean (SEM) of three determinations. Columns marked with asterisks were significantly different from controls: ${ }^{*} p \leqslant 0.05$; ${ }^{* *} p \leqslant 0 \cdot 01 ;{ }^{* *} p \leqslant 0 \cdot 001$. 


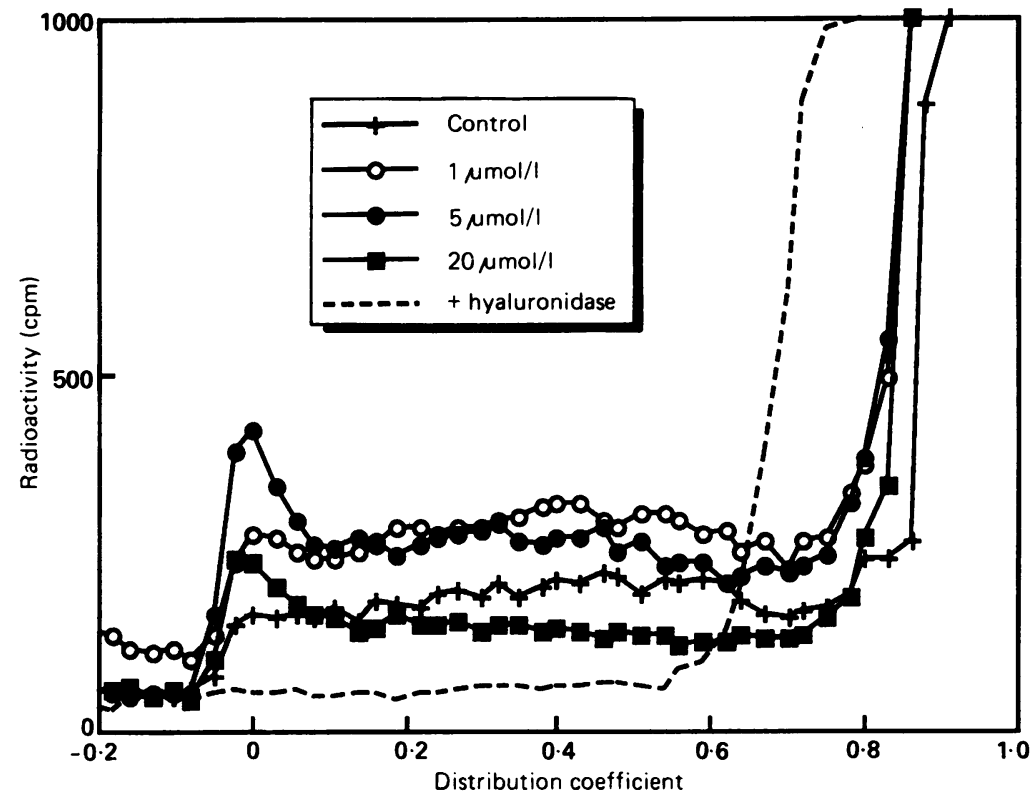

Figure 2 Sepharose CL-2B chromatograms of culture media obtained after 24 hours' incubation of synovial fibroblasts obtained from osteoarthritic joints with [ ${ }^{3} \mathrm{H}$ ] acetate alone (-+ ) and in the presence of $\mathrm{H}_{2} \mathrm{O}_{2}$ at concentrations of $20 \mu \mathrm{mol} / \mathrm{l}$ (- - ) $5 \mu \mathrm{mol} / \mathrm{l}$ (-_- ) and 1 molll before (- - ) and after (--) incubation with 5 TRU Streptomyces hyaluronidase at $60^{\circ} \mathrm{C}$ for three hours.

found in fibroblasts derived from rheumatoid arthritic joints over the entire concentration range tested (1-200 $\mu \mathrm{mol} / \mathrm{l}$ ) (fig 1B). Decreased synthesis occurred in the presence of $\mathrm{H}_{2} \mathrm{O}_{2}$ at concentrations as low as $1 \mu \mathrm{mol} / \mathrm{l}$, with maximum inhibition being found at $100 \mu \mathrm{mol} / \mathrm{l}$ (fig 1B).

The inhibitory effect of $\mathrm{H}_{2} \mathrm{O}_{2}$ on $\mathrm{HA}$ synthesis in the rheumatoid synoviocyte lines was, however, reduced by inclusion of 250 units catalase in the cultures (fig 3). One unit of catalase corresponds to the amount of enzyme which decomposes $1.0 \mu \mathrm{mol}$ of $\mathrm{H}_{2} \mathrm{O}_{2}$ per minute at $\mathrm{pH} 7 \cdot 0$. This activity was confirmed before use. Significantly, the addition of 250 units of superoxide dismutase (one unit $=$ the

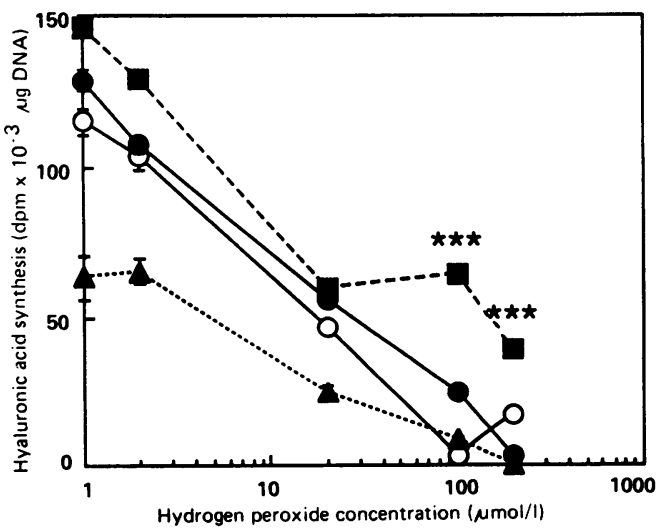

Figure 3 Effects of 250 units of superoxide dismutase (-), 250 units of catalase (- - - , or $5 \mathrm{mM}$ diethylenetriaminepenta-acetic acid (.......) on the $\mathrm{H}_{2} \mathrm{O}_{2}$ inhibition of hyaluronic acid synthesis in cultured rhewnatoid arthritic symovial fibroblasts compared with controls arthritic synovial fibroblasts compared with controls determinations. Catalase showed significant stimulation of hyaluromic acid symthesis $\left({ }^{* * *} p \leqslant 0 \cdot 001\right)$ relative to the respective controls containing $\mathrm{H}_{2} \mathrm{O}_{2}$ alone at concentrations of 100 and 200 umolll, whereas diethylemetriaminepentaacetic acid exacerbated the inhibitory effect of $\mathrm{H}_{2} \mathrm{O}_{2}$. amount of enzyme that would cause a $50 \%$ inhibition in the rate of reduction of cytochrome $c$ at $25^{\circ} \mathrm{C}, \mathrm{pH} 7 \cdot 8$ ) had no effect on the action of this oxidant on HA biosynthesis. The activity of the superoxide dismutase preparation was shown by the ferricytochrome $c$ reduction method. ${ }^{47}$ In contrast, $5 \mathrm{mM}$ diethylenetriaminepenta-acetic acid seemed to potentiate the $\mathrm{H}_{2} \mathrm{O}_{2}$ inhibition of $\mathrm{HA}$ synthesis by these cells (fig 3).

EFFECT OF $\mathrm{H}_{2} \mathrm{O}_{2}$ ON DNA SYNTHESIS

Figure 4 shows the effect of various concentrations of $\mathrm{H}_{2} \mathrm{O}_{2}$ on DNA synthesis by synovial fibroblast lines derived from rheumatoid and osteoarthritic joints. When $\left[{ }^{3} \mathrm{H}\right]$ thymidine incorporation was used as an index of DNA synthesis it was found that addition of $\mathrm{H}_{2} \mathrm{O}_{2}$ at concentrations of $2 \mu \mathrm{mol} / \mathrm{l}$ and above to the rheumatoid synoviocytes depressed the synthesis of this macromolecule (fig 4B). At concentrations of $\mathrm{H}_{2} \mathrm{O}_{2} \quad 100 \mu \mathrm{mol} / \mathrm{l}$ and above the synthesis of DNA in this cell line was almost completely inhibited. In the osteoarthritic cells, however, $\mathrm{H}_{2} \mathrm{O}_{2}$ inhibition of DNA synthesis was only evident at higher concentrations (10 $\mu \mathrm{mol} / \mathrm{l}$ and above), 70 and $80 \%$ inhibition occurring at 100 and $200 \mu \mathrm{mol} / \mathrm{l}$ of $\mathrm{H}_{2} \mathrm{O}_{2}$ respectively (fig 4A).

No effect on DNA synthesis was observed when 250 units of superoxide dismutase were added to the rheumatoid synoviocyte cultures
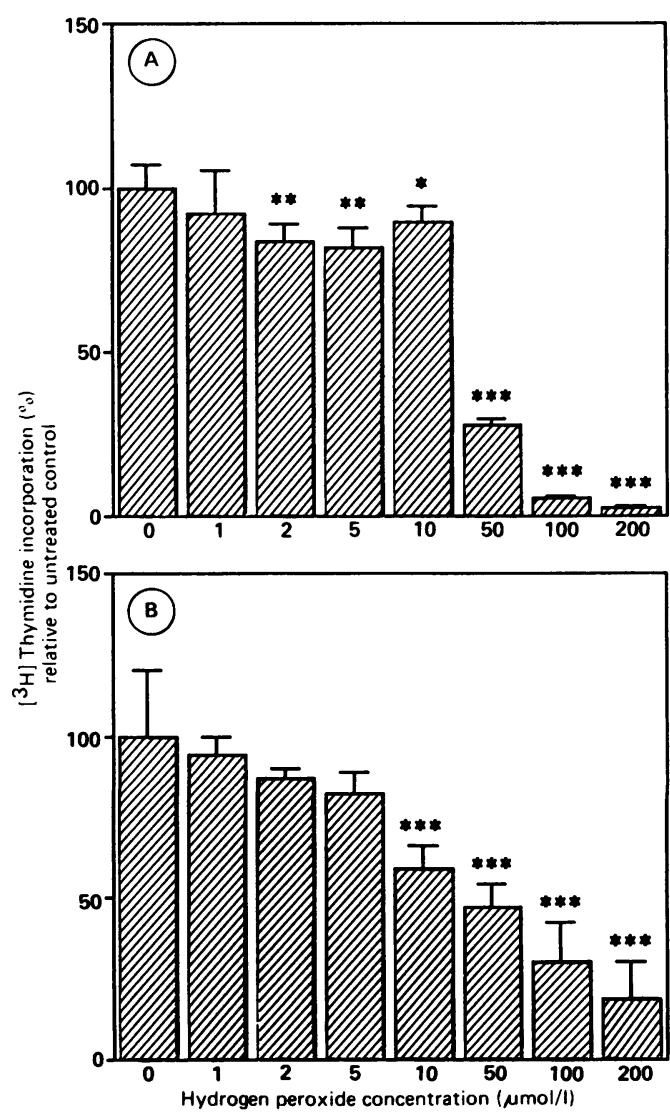

Figure 4 Effect of various concentrations of hydrogen peroxide on [ $\left.{ }^{3} \mathrm{H}\right]$ thymidine incorporation by $(A)$ osteoarthritic and $(B)$ rheumatoid arrhritic fibroblast lines. Each column represents the mean $(S D)$ of six determinations. Columns marked with asterisks were significantly different from controls: ${ }^{*} p \leqslant 0.05 ;{ }^{* *} p<0.01 ;{ }^{* * *} p \leqslant 0.001$. 


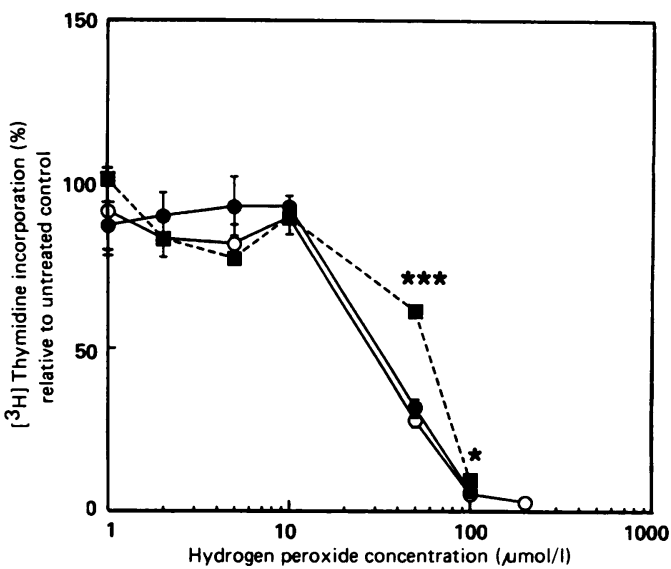

Figure 5 Effects of 250 units of superoxide dismutase (-) or 250 units of catalase (- - - ) on the $\mathrm{H}_{2} \mathrm{O}_{2}$ inhibition of DNA synthesis in a rheumatoid arthritic cell line compared with controls (-O-). Superoxide dismutase had no effect on inhibition, but catalase showed significant stimulation at 50 and 100 umolll $\mathrm{H}_{2} \mathrm{O}_{2}$ compared with their corresponding controls: ${ }^{* * *} p \leqslant 0.001 ;{ }^{*} p \leqslant 0.05$. Each point respresents the mean $(S D)$ of six determinations.

together with $\mathrm{H}_{2} \mathrm{O}_{2}$ (fig 5). On the other hand, 250 units of catalase afforded some protection, but only in the presence of $50 \mu \mathrm{mol} / 1 \mathrm{H}_{2} \mathrm{O}_{2}$. Diethylenetriaminepenta-acetic acid at a concentration of $1 \mathrm{mmol} / \mathrm{l}$ exacerbated the inhibitory effect of $\mathrm{H}_{2} \mathrm{O}_{2}$ on DNA synthesis at all concentrations (fig 6). At $5 \mathrm{mmol} / \mathrm{l}$ it caused complete inhibition of DNA synthesis even in the absence of $\mathrm{H}_{2} \mathrm{O}_{2}$ (data not shown).

EFFECT OF $\mathrm{H}_{2} \mathrm{O}_{2}$ ON THE INTEGRITY OF HUMAN SYNOVIAL FIBROBLASTS

To determine if the inhibition of $\mathrm{HA}$ and DNA synthesis produced by $\mathrm{H}_{2} \mathrm{O}_{2}$ in these cell lines was solely due to loss of cell integrity the trypan blue exclusion assay was used. The percentage of intact cells remaining after exposure to various concentrations of $\mathrm{H}_{2} \mathrm{O}_{2}$ was determined in the absence and presence of superoxide dismutase, catalase, and diethylenetriaminepenta-acetic acid. In the presence of $\mathrm{H}_{2} \mathrm{O}_{2}$ alone, up to a concentration of $20 \mu \mathrm{mol} / \mathrm{l}$, the

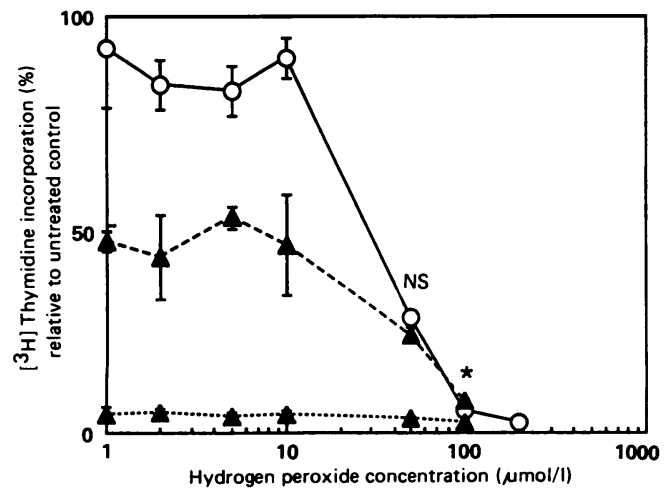

Figure 6 Effects of no diethylenetriaminepenta-acetic acid (-O-), and 1 mmolll $(--\Lambda--)$ and 5 mmoll $(. . . \Delta \ldots)$ concentrations on the $\mathrm{H}_{2} \mathrm{O}_{2}$ inhibition of DNA synthesis in fibroblasts from rheumatoid arthritic joints. All cultures containing diethylenetriaminepenta-acetic acid show significant inhibition compared with controls that contained $\mathrm{H}_{2} \mathrm{O}_{2}$ alone, except at 50 momoll $\mathrm{H}_{2} \mathrm{O}_{2}(\mathrm{NS})$, which was not significant $(p>0.05)$. ${ }^{*} p<0.05$. morphology of the rheumatoid synovial fibroblasts was not affected and their integrity remained at control level (fig 7). Above this concentration, however, cell viability declined significantly, complete cell staining occurring at $200 \mu \mathrm{mol} / \mathrm{l}$. When $5 \mathrm{mM}$ diethylenetriaminepenta-acetic acid was added to the medium at $\mathrm{H}_{2} \mathrm{O}_{2}$ concentrations as low as $1 \mu \mathrm{mol} / 1$ there seemed to be an increased toxicity compared with cultures exposed $\mathrm{H}_{2} \mathrm{O}_{2}$ alone. The addition of 250 units of superoxide dismutase to the media failed to provide protection against loss of cell integrity produced by $\mathrm{H}_{2} \mathrm{O}_{2}$ at all concentrations tested. On the other hand, addition of the same amount of catalase clearly prevented cell damage induced by $\mathrm{H}_{2} \mathrm{O}_{2}$ up to the maximum concentration used (fig 7).

\section{STABILITY OF $\mathrm{H}_{2} \mathrm{O}_{2}$ IN CELL CULTURES}

Figure 8 shows the change in $\mathrm{H}_{2} \mathrm{O}_{2}$ concentration of the incubation media over a two hour period after the addition of freshly prepared 100 $\mu \mathrm{mol} / 1 \mathrm{H}_{2} \mathrm{O}_{2}$ to cultures in the absence and presence of osteoarthritic synovial fibroblasts.

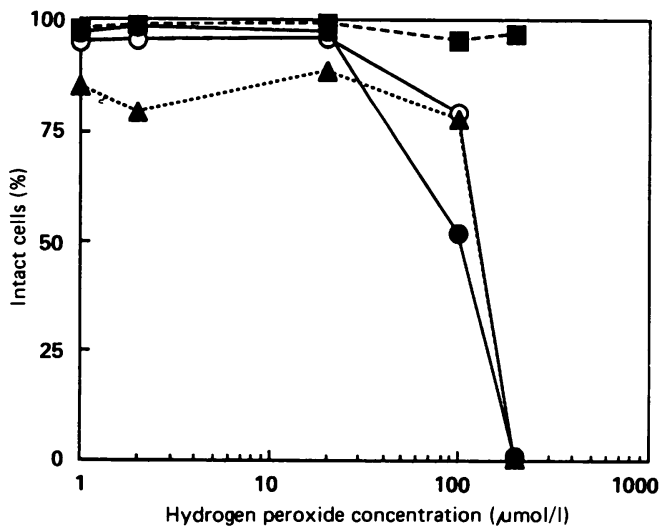

Figure 7 Effects of 250 units superoxide dismutase (-), 250 units catalase $(--\ldots)$, and $5 \mathrm{mM}$ diethylenetriaminepenta-acetic acid (.... ...) on the $\mathrm{H}_{2} \mathrm{O}_{2}$ induced loss of cell integrity assessed by trypan blue exclusion compared with controls (-O-). Data are expressed as percentage of intact cells compared with the total cell number.

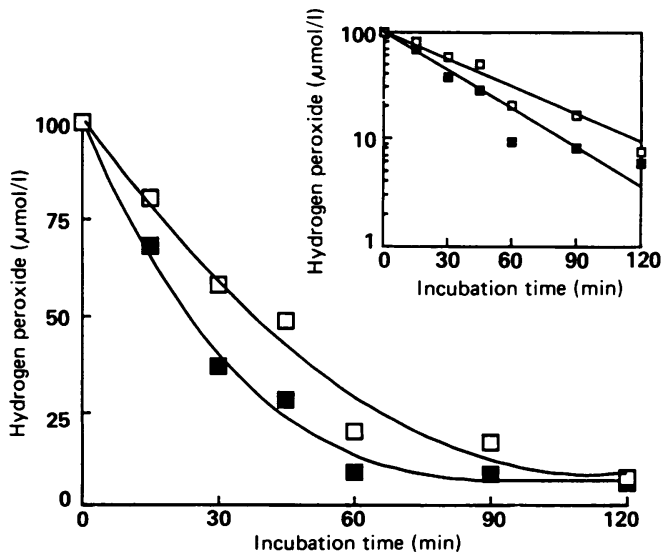

Figure 8 Kinetics of $\mathrm{H}_{2} \mathrm{O}_{2}$ elimination from the synovial cell culture media. After the addition of $100 \mu M \mathrm{H}_{2} \mathrm{O}_{2}$ the concentrations of $\mathrm{H}_{2} \mathrm{O}_{2}$ in the media in the presence $(\mathbf{a})$ and absence ( $\square$ ) of osteoarthritic synovial cells were determined at intervals. The ordinate depicts the mean of duplicate values (SD). No error bars are large enough in relation to the size of the symbol used in the diagram to be illustrated. The insert shows a linear semilogarithmic plot of the data. 
The concentration of $\mathrm{H}_{2} \mathrm{O}_{2}$ declined exponentially as a function of incubation time. The rate of change of $\mathrm{H}_{2} \mathrm{O}_{2}$ concentration in the media alone and in the presence of cells was determined by calculating the half lives $\left(t_{1 / 2}\right)$. In media alone $t_{1 / 2}$ was 45 minutes (see inset of fig 8 ), whereas in the presence of cells a more rapid decrease was observed with a half life of only 30 minutes. From these differences it was estimated that about $33 \mu \mathrm{mol} / \mathrm{l}$ of $\mathrm{H}_{2} \mathrm{O}_{2}$ was removed by the osteoarthritic synovial fibroblasts from a solution containing initially 100 $\mu \mathrm{mol} / 1 \mathrm{H}_{2} \mathrm{O}_{2}$ over a 24 hour culture period.

\section{Discussion}

In these studies we showed that exposure of human synovial fibroblasts derived from both rheumatoid arthritic and osteoarthritic joints to $\mathrm{H}_{2} \mathrm{O}_{2}$ causes alterations in their biosynthetic behaviour. This is in agreement with the observed effects of this oxygen derived species on other tissues and cells. ${ }^{25-27} 4849$ The addition of both the $\mathrm{O}_{2}^{-}$scavenger-superoxide dismutase-and diethylenetriaminepenta-acetic acid, which is a specific chelator of iron that inhibits $\mathrm{Fe}^{2+}$ dependent conversion of $\mathrm{H}_{2} \mathrm{O}_{2}$ into the highly reactive $\mathrm{OH}^{\bullet}$ radical, ${ }^{50}$ failed to reverse the inhibitory effects of $\mathrm{H}_{2} \mathrm{O}_{2}$ in the cellular system studied. This indicates that the effects noted were mediated by $\mathrm{H}_{2} \mathrm{O}_{2}$. If diethylenetriaminepenta-acetic acid penetrated the cell plasmalemma, however, it might mobilise intracellular non-protein bound divalent iron, thereby preventing $\mathrm{Fe}^{2+}$ dependent formation of hydroxyl radical in situ as has been noted with desferrioxamine. ${ }^{51}$ Further support for the role of $\mathrm{H}_{2} \mathrm{O}_{2}$ as a mediator was provided by the observation that catalase generally afforded some protection to fibroblast biosynthesis of HA and DNA and consistently prevented the loss of cell integrity as shown by the trypan blue exclusion assay (fig 7). It is noteworthy that diethylenetriaminepenta-acetic acid at the concentration used in our studies ( $5 \mathrm{mmol} / \mathrm{l}$ ), which is one tenth the concentration used by Bates et $a l^{25} 26$ in their cartilage studies, was found not only to be ineffective in abrogating the effects of $\mathrm{H}_{2} \mathrm{O}_{2}$ but exacerbated the action of this metabolite on synovial cells. Diethylenetriaminepenta-acetic acid when used alone significantly inhibited both DNA and HA synthesis, whereas superoxide dismutase or catalase had no effect or only slightly increased the synthesis of these macromolecules. The reason for these selective effects are presently unclear.

The mechanism(s) by which sublethal concentrations of $\mathrm{H}_{2} \mathrm{O}_{2}(1-100 \mu \mathrm{mol} / \mathrm{l})$ inhibit $\mathrm{HA}$ synthesis in synovial cells is presently unknown. It is clear from the data obtained (fig 7), however, that neither cell viability nor alteration in the permeability of the cell membrane, as assessed by trypan blue exclusion assay, were compromised by the oxidative potential generated in vitro by concentrations of $20 \mu \mathrm{mol} / 1$ $\mathrm{H}_{2} \mathrm{O}_{2}$ or less. This suggests that the effects produced at low concentrations of $\mathrm{H}_{2} \mathrm{O}_{2}$ are mediated by damage to intracellular components rather than through non-specific cell toxicity.
Baker and colleagues, using cartilage explant cultures, have suggested that $\mathrm{H}_{2} \mathrm{O}_{2}$ acts by oxidising the thiol ( $-\mathrm{SH})$ residue at the active site of glyceraldehyde-3-phosphate dehydrogenase. ${ }^{38}$ Inactivation of glyceraldehyde-3-phosphate dehydrogenase leads to a reduction in the rate of glycolytic ATP synthesis and subsequent depletion of intracellular ATP concentrations, resulting in a suppression of DNA, protein, proteoglycan, and HA synthesis. It is reasonable to assume that a similar oxidative 'lesion' is produced by $\mathrm{H}_{2} \mathrm{O}_{2}$ within synovial fibroblasts. As this $\mathrm{H}_{2} \mathrm{O}_{2}$ induced damage occurs intracellularly it might explain why catalase was not very effective in modulating $\mathrm{H}_{2} \mathrm{O}_{2}$ activity at low concentrations. Catalase is a large protein (mol wt 232000 ) and this may restrict its entry into the cells and thereby reduce its ability to interact with intracellular $\mathrm{H}_{2} \mathrm{O}_{2}$.

The mechanism(s) by which $\mathrm{H}_{2} \mathrm{O}_{2}$ at low concentrations stimulated $\mathrm{HA}$ synthesis in the osteoarthritic cell line (fig 1A) is still obscure. Although it is reported that thymidine incorporation by normal human dermal fibroblasts is stimulated by $\mathrm{H}_{2} \mathrm{O}_{2}$ at concentrations of $1 \mu \mathrm{mol} / 1,{ }^{49}$ this did not occur in any of our osteoarthritic or rheumatoid cell lines. As the rheumatoid synovial fibroblasts (and possibly some osteoarthritic lines) were derived from joints which had been previously exposed to oxygen derived reactive species and $\mathrm{H}_{2} \mathrm{O}_{2}$ it is possible that the intracellular activity of catalase and glutathione peroxidase, both of which serve to protect the cell, ${ }^{3}$ was exhausted. In the normal dermal fibroblast cell lines, however, sufficient amounts of these protective enzymes were present to inactivate the intracellular $\mathrm{H}_{2} \mathrm{O}_{2}$ at least at low concentrations. Possibly, cell mitosis is stimulated by a feedback mechanism which is activated when intracellular catalase or glutathione peroxidase activities, or both, are reduced by interaction with $\mathrm{H}_{2} \mathrm{O}_{2}$. Should the intracellular concentrations of $\mathrm{H}_{2} \mathrm{O}_{2}$ exceed the antioxidant concentrations present, however, oxidation of sulphydryl dependent enzymes essential for respiration-for example, glyceraldehyde-3-phosphate dehydrogenase-will occur and inhibition of metabolic activities will result. In the absence of experimental data this explanation must remain highly speculative.

Although anaerobic metabolism is well documented in rheumatoid synovial tissues, ${ }^{52} 53$ it is unlikely that these conditions would significantly alter the outcome of the present investigations as it has been shown that under aerobic and anaerobic conditions the Embden-Meyerhof glycolysis pathway remains the major energy source for these tissues. ${ }^{52}$

Our finding that $200 \mu \mathrm{mol} / 1$ of $\mathrm{H}_{2} \mathrm{O}_{2}$ was lethal to synovial cells was consistent with data reported for other cell types. ${ }^{29}{ }^{33}$ It is noteworthy that this order of concentration of $\mathrm{H}_{2} \mathrm{O}_{2}$ can be generated in vitro in only 10 minutes by $10^{6}$ activated human neutrophils. ${ }^{54}$ In the inflamed joint $10^{9}$ neutrophils may accumulate in the synovial cavity over a 24 hour period. ${ }^{11}$ When stimulated, these cells might generate sufficient $\mathrm{H}_{2} \mathrm{O}_{2}$ to cause lethal damage to synovial fibroblasts in vivo. With fewer neutrophils, or reduced stimulation, non-lethal con- 
centrations of $\mathrm{H}_{2} \mathrm{O}_{2}$ could be readily achieved within synovial joints causing intracellular damage-for example, ATP depletion or DNA breakage. ${ }^{55}$

The clearance rate of $100 \mu \mathrm{mol} / 1 \mathrm{H}_{2} \mathrm{O}_{2}$ from the culture media in the presence of either rheumatoid (data not shown) or osteoarthritic synovial cells (the calculated half life $\left(t_{1 / 2}\right)$ being 33 and 30 minutes, respectively) is in agreement with studies conducted previously using cultures of articular cartilage. ${ }^{27} 56$ The finding that $\mathrm{H}_{2} \mathrm{O}_{2}$ was depleted from the media more quickly in the presence of cells than in media alone (fig 8) strongly suggests that $\mathrm{H}_{2} \mathrm{O}_{2}$ was taken up and used by these cells. It is noteworthy, however, that the effects produced by $\mathrm{H}_{2} \mathrm{O}_{2}$ persisted beyond its elimination from the media ( $\leqslant 2$ hours) because 24 hours after incubation with synovial cells (when most of the extracellular $\mathrm{H}_{2} \mathrm{O}_{2}$ had been lost) the suppressive effects on cell metabolism were still evident. These observations are in agreement with those of Bates $e t$ al, who found prolonged inhibition of proteoglycan synthesis (five days) after two hours' exposure of bovine articular cartilage to this oxidant in vitro. ${ }^{25}$ In this connection Baker and coworkers have suggested that $\mathrm{H}_{2} \mathrm{O}_{2}$ mediated inhibition of cellular biosynthesis (HA, proteoglycan, DNA, and protein) arises from the disruption of a basal metabolic process which is required for each of these synthetic pathways to operate. ${ }^{38}$ Accordingly, it would not be surprising if some time elapses before the effects can be observed and for cells to completely regain their ability to synthesise these macromolecules.

Notwithstanding the obvious limitations associated with extrapolation of in vitro findings to the human clinical situation we suggest that $\mathrm{H}_{2} \mathrm{O}_{2}$ generated by activated inflammatory cells or from other sources within the inflamed joint may modify synovial fibroblast metabolism, particularly the biosynthesis of HA. As HA represents an essential component of synovial fluid and is responsible for its unique rheological ${ }^{57} 58$ and lubricating properties, ${ }^{5960}$ a decline in its synthesis must be considered to be contributory to the progression of the arthritic process.

We gratefully acknowledge support for this project, in the form of a postgraduate scholarship to Nongporn Hutadilok, from Roche Products Pty Ltd (Australia). We are also indebted to Ms Lynne Campbell for her help in the preparation of this manuscript.

1 Zvaifler N J. Rheumatoid arthritis: epidemiology, etiology, rheumatoid factor, pathology, pathogenesis. In: Schumacher Jr H R, ed. Primer on the rheumatic diseases. Atlanta: Arthritis Foundation, 1988: 83-7.

2 Curnutte J T, Babior B M. Chronic granulomatous disease. Adv Hum Genet 1987; 16: 229-97.

Adv Hum Genet 1987; 16: 229-97.
3 Fantone J C, Ward P C. Role of oxygen derived free radicals and metabolites in leukocyte-dependent inflammatory and metabolites in leukocyte-dependent

$4 \mathrm{McC}$ react J M. Free radicals and inflammation protection of synovial fluid by superoxide dismutase. Science 1974; 185

5 Del Maestro R F, Arfors K-E, Lindblom R. Free radical depolymerisation of hyaluronic acid: influence of scavenger substances. In: Lewis D H, ed. 10th European conference of microcirculation, Cagliari, 1978. Bibl Anat Basel: Karger, 1979; No. 18: 132-5.

6 Greenwald R A, Moy W W. Effect of oxygen-derived free radicals on hyaluronic acid. Arthritis Rheum 1980; 23 455-63.
7 Wong S F, Halliwell B, Richmond R, Showroneck W R. The role of superoxide and hydroxyl radicals in the degradation of hyaluronic acid induced by metal ions and by ascorbic acid. F Inorg Biochem 1981; 14: 127-34.

8 Andley U P, Chakrabarti B. Role of singlet oxygen in the degradation of hyaluronic acid. Biochem Biophys Res Commun 1983; 115: 894-901.

9 McNeil J D, Wiebkin O W, Bettes W H, Cleland L G. Depolymerisation products of hyaluronic acid after exposure to oxygen-derived free-radicals. Ann Rheum Dis 1985; 44: to oxy 780 .

10 Baker $\dot{M}$ S, Green S P, Lowther D A. Changes in the viscosity of hyaluronic acid after exposure to a myeloperoxidase-derived oxidant. Arthritis Rheum 1989; 32 461-7.

11 Blake D R, Allen R E, Lunec J. Free radicals in biological systems: a review orientated to inflammatory processes. $B r$ Med Bull 1987; 43: 371-85.

12 Edwards S W, Hallett M B, Campbell A K. Oxygen-radical production during inflammation may be limited by oxygen concentration. Biochem 7 1984; 217: 851-4.

13 Lund-Olesen K. Oxygen tension in synovial fluids. Arthritis Rheum 1970; 13: 769-76.

14 Blake D R, Hall N D, Treby D A, Halliwell B, Gutteridge J M C. Protection against superoxide and hydrogen peroxide in synovial fluid from rheumatoid patients. Clin peroxide in synovial

15 Biemond P, Swaak A J G, Koster J F. Protective factors against oxygen free radicals and hydrogen peroxide in rheumatoid arthritis synovial fluid. Arthritis Rheum 1984 27: 760-5.

16 Marklund S L, Bjelle A, Elmqvist L G. Superoxide dismutase isoenzymes of the synovial fluid in rheumatoid arthritis and in reactive arthritides. Ann Rheum Dis 1986; 45: 847-51.

17 Zoschke D C, Kaja J. Suboptimal levels of hydrogen peroxide scavengers in synovial fluid: in vitro augmentation with slow acting antirheumatic drugs. F Rheumatol 1989; 16

18 Greenwald R A, Moy W W, Lazarus D. Degradation of cartilage proteoglycans and collagen by superoxide radical cartilage proteoglycans and collage
Arthritis Rheum 1976; 19: 799.

19 Bates E J, Harper G S, Lowther D A, Preston B N. Effect of oxygen derived reactive species on cartilage proteoglycanhyaluronate aggregates. Biochem Int 1984; 8: 629-37.

20 Bartold P M, Wiebkin O W, Thonard J C. The effect of oxygen-derived free radicals on gingival proteoglycans and hyaluronic acid. $\mathcal{F}$ Periodont Res 1984; 19: 390-400.

21 Chung M H, Kesner L, Chan P C. Degradation of articular cartilage by copper and hydrogen peroxide. Agents Actions cartilage by coppe

22 Dean R T, Roberts C R, Forni L. Oxygen-centred free radicals can efficiently degrade the polypeptide of proteoglycans in whole cartilage. Biosci Rep 1984; 4: 1017-26.

23 Roberts C R, Mort J S, Roughley P J. Treatment of cartilage proteoglycan aggregate with hydrogen peroxide: relation ship between observed degradation products and those that occur naturally during aging. Biochem $\mathcal{F} 1987 ; 247$ : 349-57.

24 Roberts C R, Roughley P J, Mort J S. Degradation of human proteoglycan aggregate induced by hydrogen peroxide:
protein fragmentation, amino acid modification and hyaluronic acid cleavage. Biochem $f$ 1989; 295: 805-11.

25 Bates E J, Johnson C C, Lowther D A. Inhibition of proteoglycan synthesis by hydrogen peroxide in cultured proteoglycan synthesis by hydrogen peroxide in cultured
bovine articular cartilage. Biochim Biophys Acta 1985; 838: 221-8.

26 Bates E J, Lowther D A, Johnson C C. Hyaluronic acid synthesis in articular cartilage: an inhibition by hydrogen peroxide. Biochem Biophys Res Commun 1985; 132: 714-20.

27 Schalkwijk J, van den Berg W B, van de Putte L B, Joosten L A B. Hydrogen peroxide suppresses the proteoglycan synthesis of intact articular cartilage. $\mathcal{f}$ Rheumato 1985; 12: 205-10.

28 Weiss S J, Young J, Lobuglio A F, Slivka A, Nimeh N F. Role of hydrogen peroxide in neutrophil-mediated destruction of cultured endothelial cells. $\mathcal{F}$ Clin Invest 1981; 68: 714-21.

29 Ager A, Gordon J L. Differential effects of hydrogen peroxide on indices of endothelial cell function. $\mathcal{F} E \times p$ Med peroxide on indices

30 Simon R H, Scoggin C H, Patterson D. Hydrogen peroxide causes the fatal injury to human fibroblasts exposed to causes the fatal injury to human fibroblasts expos
oxygen radicals. $\mathcal{F}$ Biol Chem 1981; 256: 7181-6.

31 Noel-Hudson M S, De Belilovsky C, Petit N, Lindenbaum A, Wepierra J. In vitro cytotoxic effects of enzymatically induced oxygen radicals in human fibroblasts: experimenta procedures and protection by radical scavengers. Toxic In Vitro 1989; 3: 103-9.

32 Suttorp N, Simon L M. Importance of the glutathione redox cycle for the resistance of lung epithelial cells against polymorphonuclear leukocyte-mediated oxidant attack. Biochem Pharmacol 1986; 35: 2268-70.

33 Rubin R, Farber J L. Mechanisms of the killing of cultured hepatocytes by hydrogen peroxide. Arch Biochem Biophys 1984; 228: 450-9.

34 Nathan C F, Arrick B A, Murray H W, de Santis N M, Cohn Z A. Tumor cell antioxidant defences: inhibition of the $Z$ A. Tumor cell antioxidant defences: inhibition of the glutathione redox cycle enhances macro
cytosis. F Exp Med 1981; 153: 766-82.

35 Mello-Filho A C, Meneghini R. In vivo formation of single strand breaks in DNA hydrogen peroxide is mediated by the Haber-Weiss reaction. Biochim Biophys Acta 1984; 781 56-63.

36 Schraufstätter I U, Hinshaw D B, Hyslop P A, Spragg R G, Cochrane C G. Oxidant injury of cells: DNA strand-breaks 
activate polyadenosine disphosphate-ribose polymerase and lead to depletion of nicotinamide adenine dinucleotide. f Clin Invest 1986; 77: 1312-20.

37 Hyslop P A, Hinshaw D B, Halsey Jr W A, et al. Mechanisms of oxidant-mediated cell injury: the glycolytic and mitochondrial pathways of ADP phosphorylation are major chondrial pathways of ADP phosphorylation are major intracellular targets inactivated by

38 Baker M S, Feigan J, Lowther D A. The mechanism of chondrocyte hydrogen peroxide damage: depletion of intracellular ATP due to suppression of glycolysis caused by oxidation of glyceraldehyde-3-phosphate dehydrogenase. F Reumatol 1989; 16: 7014

39 Hoffstein S T, Gennao D E, Meunier P C. Cytochemical demonstration of constitutive $\mathrm{H}_{2} \mathrm{O}_{2}$ production by macrophages in synovial tissue from rats

40 Smith M M, Ghosh P. The synthesis of hyaluronic acid by human synovial fibroblasts is influenced by the nature of human synovial fibroblasts is influenced by the nature of Int 1987; 7: 113-22.

41 Dayer J M, Krane S M, Russel G G, Robinson D R. Production of collagenase and prostaglandins by isolated adherent rheumatoid synovial cells. Proc Natl Acad Sci USA 1976; 73: 945-9.

42 Verbruggen G, Veys E M. Influence of sulphated glycosaminoglycans upon proteoglycan metabolism of the synovial lining cells. Acta Rheumatologica Belgica 1977; 1: 75-92.

43 Burton $K$. Determination of DNA concentration with diphenylamine. Methods Enzymol 1968; 12: 163-6.

44 Vogel A I. A text-book of quantitative inorganic analysis. 3rd ed. London: Longmans, 1961: 295-6.

45 Pick E, Keisari Y. A simple colorimetric method for the measurement of hydrogen peroxide produced by cells in culture. F Immunol Methods 1980; 38: 161-70.

46 Pick E. Microassays for superoxide and hydrogen peroxide production and nitroblue tetrazolium reduction using an
enzyme immunoassay microplate reader. Methods Enzymol enzyme immunoassay

47 Flohé L, Otting F. Superoxide dismutase assays. Methods Enzymol 1984; 105: 93-104.

48 Metzger Z, Hoffeld J T, Oppenheim J J. Suppression of fibroblast proliferation by activated macrophages: involvement of $\mathrm{H}_{2} \mathrm{O}_{2}$ and a non-prostaglandin $\mathrm{E}$ product of the ment of $\mathrm{H}_{2} \mathrm{O}_{2}$ and a non-prostaglandin $\mathrm{E}$ product of the
cyclooxygenase pathway. Cell Immunol 1986; 100: 501-14.
49 Murrell G A C, Francis M J O, Bromley L. Stimulation of fibroblast proliferation by oxygen free radicals. In: Maddison P, ed. The Strangeways Research Lab 75th anniversary symposium, Cambridge, 1987. Proceedings No 2. London: The Arthritis and Rheumatism Council for Research, 1987: 117-22.

50 Halliwell B. Superoxide-dependent formation of hydroxy radicals in the presence of iron salts: its role in degradation radicals in the presence of iron salts: its role in degradation
of hyaluronic acid by a superoxide generating system. of hyaluronic acid by a supero

51 Blake D R, Winyard P, Lunec J, et al. Cerebral and ocular toxicity induced by desferrioxamine. $Q \mathcal{F}$ Med 1985; 56: 345-55.

52 Roberts J E, McLees B D, Kerby G P. Pathways of glucose metabolism in rheumatoid and nonrheumatoid synovial membrane. F Lab Clin Med 1967; 70: 503-11.

53 Goetzl E J, Falchuk K H, Zeiger L S, et al. A physiological approach to the assessment of disease activity in rheumaapproach to the assessment of disease activity

54 Ruch W, Cooper P H, Baggiolini M. Assay of $\mathrm{H}_{2} \mathrm{O}_{2}$ production by macrophages and neutrophils with homoproduction by macrophages and neutrophils with homovanillic acid and horse-radi
Methods 1983; 63: 347-57.

55 Junod A F, Petersen H, Jornot L. Differential effects of hyperoxia and $\mathrm{H}_{2} \mathrm{O}_{2}$ on DNA damage, poly (ADP-ribose) polymerase activity, NAD and ATP content in cultured endothelial cells and fibroblasts. Am Rev Respir Dis 1988; 137 (suppl): 83.

56 Baker M S, Feigan J, Lowther D A. Chondrocyte antioxidant defenses: the roles of catalase and glutathione peroxidase in protection against $\mathrm{H}_{2} \mathrm{O}_{2}$ dependent inhibition of proteoprotection biosynthesis. $\mathcal{F}$ Rheumatol 1988; 15: 670-7.

57 Balazs E A, Gibbs O A. The rheological properties and biological function of hyaluronic acid. In: Balazs E A, ed. Chemistry and molecular biology in the intercellular matrix. Chemistry and molecular biology in the intercellular mat
Vol 3. New York: Academic Press, 1970: 1241-53.

58 Bothner $\mathrm{H}$, Wik $\mathrm{O}$. Rheology of hyaluronate. In: Anniko M, Hellström S, Fellenius E, eds. Minisymposium on Hyaluronan and its use in clinical otology, Uppsala, 1986. Acta Otolaryngol Stockholm: Almqvist and Wiksell, 1987; 442 (suppl): 25-30.

59 Langer $H$ E, Altmann S, Luhrs $W$, Zeidler $H$. The lubrication of the natural joint: influence of the viscosity of hyaluronic acid on the friction in the human hip. $\mathcal{F}$ Biomech 1987; 20: 806 .

60 Hills B A. The biology of surfactant. Cambridge: Cambridge University Press, 1988: 267-300. 